IJMS 17 (2), 201-224 (2010)

\title{
MODEL PEMPROSESAN MAKLUMAT KOGNITIF DAN PEMBUATAN KEPUTUSAN: TEORI DAN AMALAN DALAM SISTEM PENILAIAN PRESTASI PEKERJA SEKTOR AWAM DI MALAYSIA
}

\author{
RUSLI AHMAD \\ Fakulti Sains Kognitif dan Pembangunan Manusia \\ Universiti Malaysia Sarawak
}

\begin{abstract}
Abstrak
Kajian ini bertujuan untuk melihat kaitan amalan pembuatan keputusan dengan prestasi pekerja sektor awam di Malaysia dengan memberi perhatian kepada aspek pemprosesan maklumat kognitif. Tumpuan kepada sistem pemprosesan maklumat kognitif yang terlibat secara menyeluruh dibuat memandangkan pentingnya penggunaan maklumat dalam sebarang pembuatan keputusan dan tiada kajian yang komprehensif tentang perkara yang berkaitan dibuat sehingga kini. Penyelidikan yang dijalankan adalah bersifat kuantitatif. Sampel kajian terdiri daripada 199 pegawai penilai prestasi yang dipilih berdasarkan persampelan rawak mudah. Soal selidik yang berkaitan telah dibina dan 155 borang soal selidik yang lengkap telah digunakan untuk tujuan analisis. Hasil kajian menunjukkan tidak terdapat perbezaan yang signifikan antara pegawai penilai novis dan pakar dalam semua fasa yang terlibat dalam model pemprosesan maklumat kognitif kecuali untuk faktor pemerhatian 1. Ini bermakna tidak terdapat perbezaan yang signifikan antara pegawai penilai novis dan pakar dalam pelaksanaan pemerhatian, pengkategorian, penyimpanan, pengingatan semula, pengintegrasian dan pembuatan keputusan. Kajian ini penting kepada pembuat dasar, pengamal sumber manusia dan pereka program latihan untuk membaiki aspek pelaksanaan penilaian prestasi yang menjadi amalan penting bagi organisasi. Kajian ini juga membuka ruang kepada pemahaman yang lebih menyeluruh dari segi amalan pembuatan keputusan berkaitan penilaian prestasi pekerja dengan mendekatinya dari aspek kognitif proses yang terlibat. Pemahaman yang lebih mendalam dan menyeluruh ini diharap akan membuka ruang kepada pelaksaaan satu sistem penilaian prestasi yang diterima ramai dan adil.
\end{abstract}

Kata kunci: Pembuatan keputusan; penilaian prestasi; sistem pemprosesan maklumat. 


\begin{abstract}
Purpose - This paper seeks to understand the decision-making process in a performance appraisal decision by looking at the cognitive information processing aspects involved. This paper therefore concentrates on the practice of cognitive processing model in the Malaysian public service performance appraisal system. Raters' understanding on their approaches to appraisal decision making are explored for evidence of the cognitive processing system, alongside considerations of the attitudes toward practice in the specific cognitive processing model phases.
\end{abstract}

Design/Methodology/Approach - Non-experimental design by using quantitive research methodology was used to explore the perception of the raters' to the practice of cognitive processing model phases. Questionnaire survey was chosen as a specific method or technique for data collection because of the effectiveness and advantages of this technique. A total of 199 questionnaires were distributed to 34 high schools and from that, $77.9 \%$ of questionnaires were returned and were usable for data entry. With regard to the statistical inference, the researcher used the t-test to identify the difference in perception of the raters.

Findings - Overall, results from the questionnaire survey clearly showed that raters have a positive attitude toward the practice of cognitive processing model phases in their performance appraisal decision. Mean values over 3.0 and $t$-test results were found to be very significant from the mid-point 3.0 $(p<0.01)$. This indicated that raters have a clear understanding and positive attitude toward cognitive processing phases and realise the importance of these steps in performance appraisal decision.

Originality/Value - This research paper is important because it will offer understanding on the cognitive processing model phases practised by raters in the performance appraisal decision. Exploration of the cognitive maps of raters can provide insight into how raters make their decisions. The role of raters in the implementation of the performance appraisal system can also be explored. Previous studies on performance appraisal system in the Malaysian Public Service had tended to focus on other aspects. Therefore, the main significance of this study lies in it being the first study of cognitive maps of raters' cognitive processing model in the Malaysian context. Although a few studies had been done on the cognitive processing model phases, these were mainly focused on the investigation of single stages or issues related to the cognitive processing model, rather than exploring it as a whole process. This study will enable academics, practitioners, and policy makers to understand the process behind performance appraisal decisions. Comparison between the raters' cognitive maps can also take place.

202 IJMS 17 (2), 201-224 (2010) 
Keywords - Cognitive processing model; decision making; information processing system; performance appraisal; public sector.

Paper type - Research paper.

\section{Pengenalan}

Maklumat adalah penting dalam pembuatan keputusan. Pembuatan keputusan sebagai timbal baliknya akan menjadi 'pincang' tanpa maklumat. Dalam apa sahaja pembuatan keputusan, sama ada secara individu, kelompok atau pun organisasi, maklumat atau informasi adalah sangat penting. Salah satu aspek pembuatan keputusan yang sangat penting dalam organisasi adalah berkaitan dengan penilaian prestasi pekerja (Rusli Ahmad, 2007). Adalah satu perkara yang silap jika pihak pengurusan kurang menekankan kepada kepentingan perkara ini dan sebaliknya hanya memberi penekanan kepada perkara yang berkaitan dengan pengembangan syarikat atau organisasi. Seringkali organisasi hanya menekankan aspek pembangunan organisasi dari aspek pengambilan pekerja baru, pembelian mesin, pembinaan bangunan, penambahan pelaburan atau pengembangan aktiviti syarikat dan kurang menekankan aspek penjagaan kebajikan pekerja dari segi sistem upah atau gaji yang ditawarkan. Sebenarnya sistem upah atau gaji yang dilaksanakan mempunyai kesan yang besar kepada pekerja secara keseluruhan (Armstrong, 1998; Bratton \& Gold, 1999). Furnham (1994) dalam kajiannya mendapati sistem upah mempunyai kaitan yang kuat dengan motivasi, kadar pusing ganti kerja dan komitmen pekerja. Sistem upah atau gaji yang dilaksanakan sebenarnya mempunyai kaitan langsung kepada pendapatan harian, bulanan dan tahunan pekerja. Kepentingan sistem upah dan gaji di mata pekerja tidak dapat dinafikan oleh mana-mana pihak (Perry, 1995; Bartol \& Locke, 2000; Millward, Bryson \& Forth, 2000). Walau bagaimanapun perlu diingat sistem upah yang ditawarkan bukanlah menjadi matlamat utama bagi semua pekerja dalam organisasi. Ditinjau dari aspek pengurusan strategik organisasi, sesungguhnya menjaga kebajikan pekerja adalah sangat penting kepada kelangsungan (survival) organisasi (Argyris, 1994). Makalah penyelidikan ini berminat untuk meneroka penggunaan sistem pemprosesan maklumat kognitif dalam penilaian prestasi pekerja sektor awam di Malaysia. Untuk itu satu liputan ringkas berkaitan dengan Teori Sistem Pemprosesan Maklumat adalah difikirkan relevan. 


\section{Teori Sistem Pemprosesan Maklumat}

Model sistem pemprosesan maklumat manusia mengandaikan manusia sebagai organisma yang berkait langsung dengan sistem komunikasi. Manusia memperolehi maklumat daripada pelbagai sumber dan digunakan untuk pelbagai perkara. Maklumat menjadi media atau alat perantara dalam sistem komunikasi manusia untuk menyelesai masalah dan membuat keputusan. Dalam konteks pembuatan keputusan pekerja, peranan sistem pemprosesan maklumat adalah tidak dinafikan kepentingannya. Ini bagi mewujudkan pembuatan keputusan yang adil dan dapat diterima ramai. Ramai pihak berpendapat, pembuatan keputusan berkaitan prestasi pekerja adalah satu aktiviti rutin dan dapat dikatakan satu perkara yang mudah dan jelas pelaksanaannya. Sesungguhnya penilaian prestasi pekerja perlu dilihat sebagai satu proses dan merupakan satu aktiviti yang kompleks. Proses ini melibatkan satu jangka masa tertentu (biasanya prestasi untuk setahun), mempunyai struktur tugas tertentu yang diambil kira dan melibatkan hubungkait yang sangat rapat antara pekerja dengan tugas dan peranan yang dimainkan dan pelbagai aspek lain yang bersangkutan antara individu dan organisasi. Sebenarnya penilaian prestasi pekerja bukanlah semudah seperti yang dijangkakan (Rusli Ahmad, 2007). Penilaian prestasi melibatkan hubung kait yang pelbagai hala di mana penilai prestasi menilai pekerja di bawah tanggungjawabnya berdasarkan satu set piawai yang telah ditetapkan atau diterima pakai. Proses ini melibatkan banyak pihak dan melibatkan satu proses manipulasi mental yang rumit (Rusli Ahmad, 2008). Sering kali dari segi amalan, penilai biasanya menjalankan penilaian atau semakan semula terhadap prestasi pekerja selepas tiga (3) bulan, enam (6) bulan atau cuma di akhir tahun. Sesungguhya penilaian yang dijalankan adalah untuk mengukur prestasi pekerja bagi sepanjang tahun. Pentingnya melihat penilaian prestasi pekerja sebagi satu proses yang berterusan telah ditekankan ramai penyelidik (Danerson 1994; Armstrong 1999).

Model pemprosesan maklumat mengandaikan bahawa maklumat adalah alat bagi saluran komunikasi yang penting bagi manusia. Model ini menekankan beberapa perkara utama, iaitu sumber maklumat, alat pengantar, saluran komunikasi dan destinasi yang dituju. Dalam proses perantara, informasi telah dikodkan dan selepas itu dihantar melalui saluran tertentu ke destinasi yang ditetapkan sebelum menjalani proses pembuatan keputusan. Urutan proses berkenaan diringkas dalam Rajah 1. 


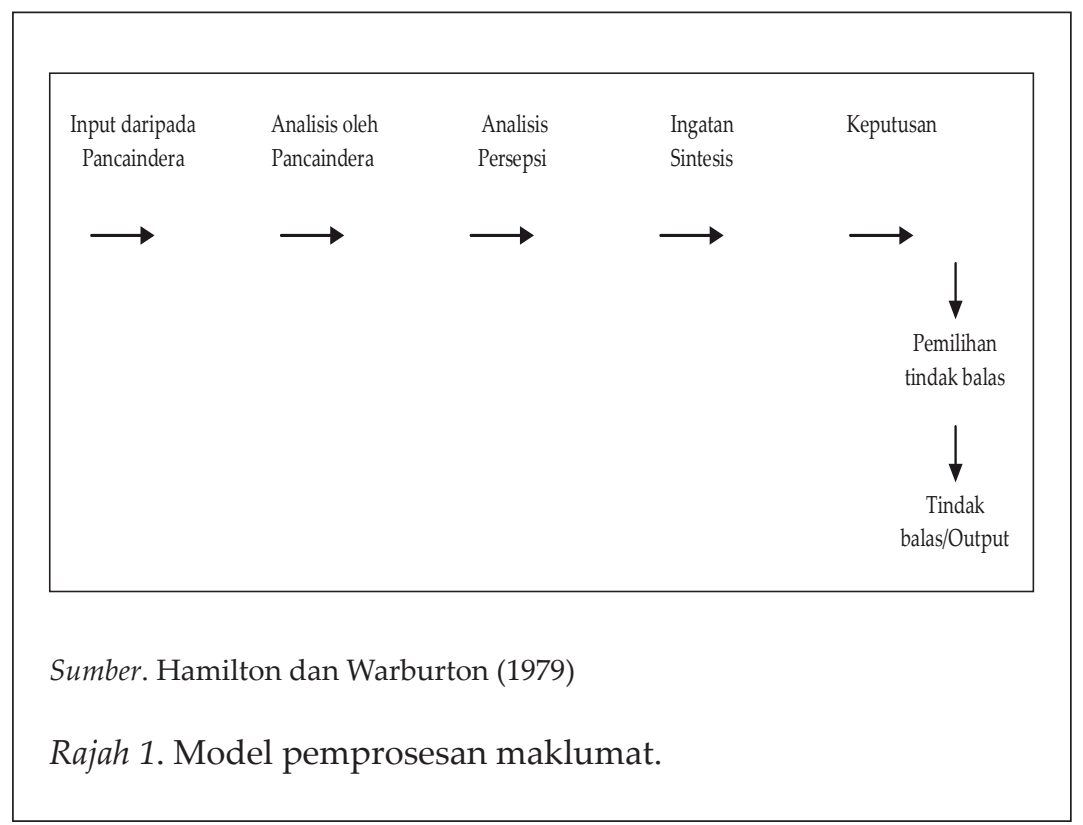

\section{Model Pemprosesan Maklumat Kognitif}

Neisser (1967) memberi definisi proses kognitif sebagai keseluruhan proses di mana input daripada pancaindera mengalami proses penukaran, pengurangan, penyimpanan, ingatan semula dan penggunaan. Sebenarnya istilah proses kognitif sering kali dikaitkan dengan operasi minda. Menurut Danerson (1994), proses kognitif merangkumi segala aktiviti mental atau pernyataan akal yang melibatkan pengetahuan dan maklumat termasuklah persepsi, penumpuan, ingatan, penakulan, fungsi bahasa, proses pembangunan, penyelesaian masalah dan juga termasuklah hubungan atau interaksi antara manusia dan mesin serta juga kepintaran buatan.

Proses kognitif dapat dibahagikan kepada dua peringkat, iaitu proses kognitif asas dan proses kognitif tahap tinggi. Peringkat kognitif asas termasuklah proses membuat persepsi yang melibatkan penumpuan dan pembentukan konsep serta juga proses ingatan seperti pemprosesan maklumat. Proses kognitif tahap tinggi pula melibatkan proses penakulan, penyelesaian masalah, pembuatan keputusan, pemahaman dan penggunaan bahasa dan meta kognitif. Kedua-dua tahap ini berhubungan antara satu sama lain dan tidak terpisah. Proses tahap tinggi bergantung kepada integrasi proses yang tinggi dalam tahap asas. 
Proses kognitif dalam penilaian prestasi adalah berkait rapat dengan penyelidikan dalam bidang kognitif dan psikologi sosial (Wyer \& Srull, 1982). Penilai membuat pemerhatian tingkah laku pekerja dalam organisasi dan dalam masa yang sama dari segi kognitifnya memproses segala maklumat yang berkaitan. Penilai membuat kategori dan kemudian membuat keputusan berkaitan prestasi pekerja sama ada memuaskan atau sebaliknya. Model ini seringkali dirujuk sebagai model pemprosesan maklumat sosial kerana penilai membuat penilaian berkaitan dengan manusia dan bukannnya objek yang kaku.

Salah satu model kognitif berkaitan dengan penilaian prestasi adalah dicadangkan oleh DeNisi, Cafferty dan Meglino (1984). Model ini mengandaikan penilai sebagai individu yang aktif mencari maklumat yang berkaitan prestasi pekerja. Model ini melihat penilaian prestasi sebagai satu proses latihan berkaitan dengan persepsi sosial dan kognitif. Model ini memberi perhatian serius untuk aspek kepekaan penilai kepada keperluan mencari maklumat. Ini akan mempengaruhi apakah aspek tingkah laku pekerja yang diperhatikan. Model ini mengandaikan penilai mentafsir prestasi seseorang pekerja berdasarkan skema atau kategori tertentu yang telah sedia ada. Skema dan kategori yang digunakan mempunyai kesan terhadap struktur maklumat yang dikumpul. Kategori dan skema biasanya akan mempengaruhi model pemprosesan maklumat kognitif dan melibatkan semua peringkat dalam pembuatan keputusan.

Setiap aspek atau komponen dalam proses penilaian adalah sangat penting. Jika maklumat berkaitan prestasi pekerja yang penting tidak diberi penilaian sewajarnya, penilaian prestasi pekerja yang tidak tepat dan sempurna akan berlaku. Dalam perkataan yang mudah, proses penilaian prestasi melibatkan dua proses utama, iaitu pemerhatian dan penghakiman. Pemerhatian melibatkan proses pengesanan, persepsi dan ingatan semula manakala, proses penghakiman melibatkan proses mengkategori, integrasi dan penilaian semula terhadap sumber atau maklumat yang diterima.

Perbincangan berkaitan model pemprosesan maklumat kognitif telah dijalankan oleh ramai pengkaji dan sarjana. Mereka berbeza pendapat tentang fasa-fasa yang terlibat dalam model pemprosesan maklumat kognitif. Setengah penyelidik cuma menekankan kepada empat (4) fasa (Landy \& Farr, 1980; Wofford \& Goodwin, 1990), manakala yang lain memberi perhatian kepada lima (5) fasa (Feldman, 1981; Landy \& Farr, 1983; Wofford \& Goodwin, 1990; Beck De, O'Sullivan \& Boh Le, 1995). Terdapat juga penyelidik dan sarjana yang menekan kepada enam (6) fasa utama (DeNisi et al., 1984; Murphy \& Cleveland, 1995; 
DeNisi, 1996). Analisa proses dalam model kognitif pemprosesan maklumat dalam kajian ini menggunakan model enam (6) fasa yang dikemukakan oleh DeNisi dan rakan-rakan (1984), Murphy dan Cleveland (1995) dan DeNisi (1996). Ini kerana model ini mengambil kira dan membincangkan secara keseluruhan proses yang terlibat secara lebih menyeluruh. Rajah 2 menerangkan model pemprosesan maklumat yang digunakan dalam kajian ini dan model ini dikenal pasti selepas membuat analisis terperinci tentang perbincangan yang dibuat oleh pengkaji dan sarjana dalam bidang berkenaan. Secara umum model ini menegaskan penilai prestasi akan membuat pemerhatian berkaitan tingkah laku pekerja, menyimpan maklumat berkaitan dengannya untuk beberapa lama dan menggunakan maklumat itu kemudian apabila tiba masa pembuatan keputusan dijalankan. Andaian yang digunakan dalam model ini ialah maklumat berkaitan pekerja dan prestasinya yang terdahulu adalah signifikan dalam mempengaruhi pembuatan keputusan. Proses kategori awal ini mempengaruhi segala fasa lain dalam penilaian prestasi seperti pemerhatian, pengkategorian, penyimpanan, pengingatan kembali, pengintegrasian dan pembuatan keputusan.

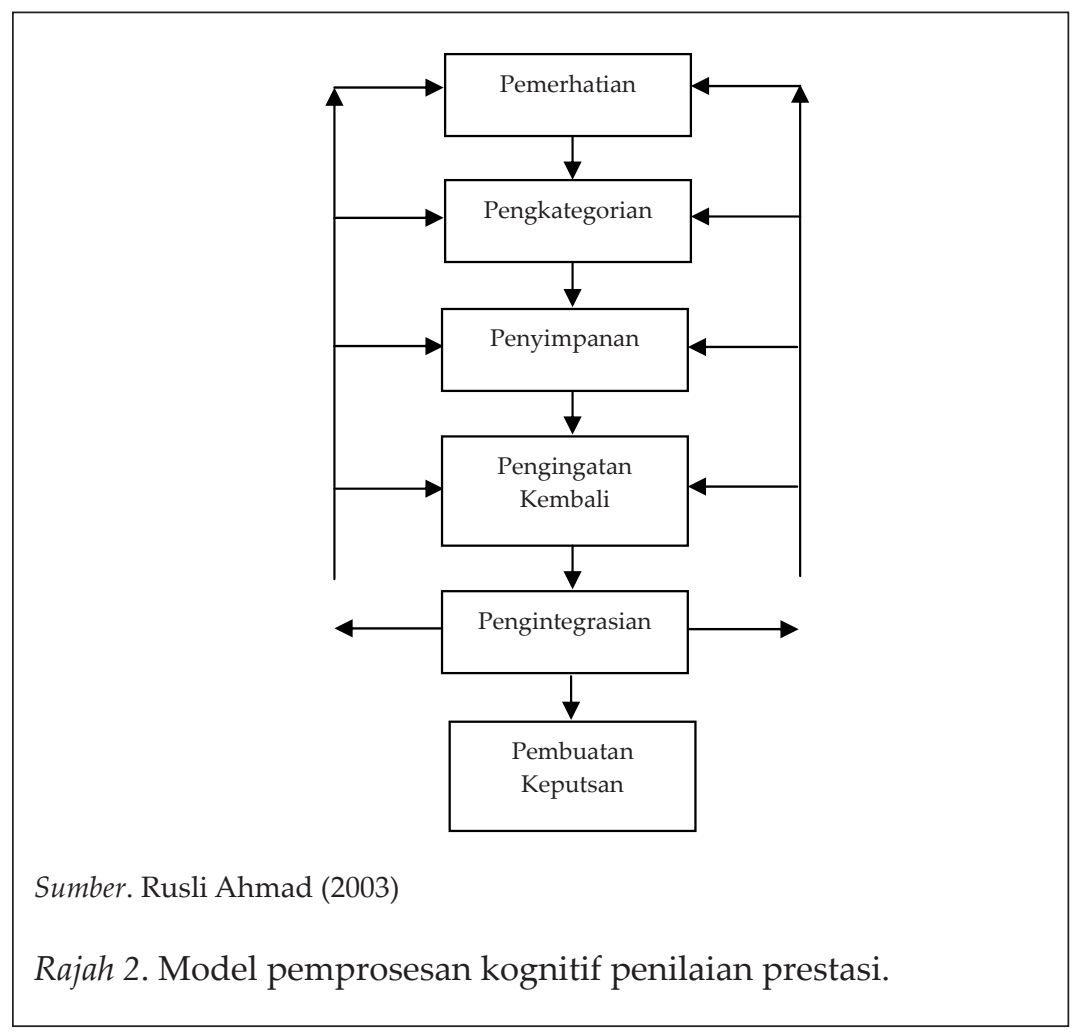

IJMS 17 (2), 201-224 (2010) 
Fasa pertama dalam model pemprosesan maklumat kognitif ialah pemerhatian. Pemerhatian boleh didefinisikan sebagai pemerhatian sistematik ke atas tingkah laku prestasi pekerja untuk maksud membuat penilaian prestasi. Maklumat berkaitan pemerhatian disimpan dalam ingatan penilai (Murphy \& Cleveland, 1995). Tujuan pemerhatian sangat penting kerana ini akan membawa kesan langsung kepada ketepatan dan penentuan prestasi pekerja. Pengkategorian pula merujuk kepada proses di mana maklumat yang pelbagai itu dipermudahkan dalam bentuk dimensi dan kategori tertentu berdasarkan prestasi pekerja. Proses ini bergantung kepada ciri-ciri persamaan antara sasaran dan maklumat yang diperhati daripada setiap individu. Penyimpanan pula merujuk kepada proses yang berlaku dalam ingatan penilai hasil daripada pemerhatian yang dijalankan. Proses ingatan ini melibatkan ingatan jangka masa pendek dan ingatan jangka masa panjang. Fasa yang keempat ialah pengingatan kembali kepada maklumat yang disimpan. Fasa ini melibatkan ingatan semula dan pengiktirafan (recognition). Ingatan semula mewakili secara relatifnya usaha untuk mengingatkan kembali maklumat yang dibuat secara tidak berstruktur. Manakala pengiktirafan pula adalah percubaan untuk stimulus maklumat berdasarkan maklumat yang disimpan dalam data penyimpanan jangka panjang penilai. Pengintegrasian pula merujuk kepada proses di mana maklumat yang pelbagai berkaitan prestasi pekerja semasa fasa pemerhatian, pengkategorian, penyimpanan dan pengingatan kembali dan pengintegrasian. Proses ini mengambil kira maklumat yang terdahulu dan juga yang terbaharu dengan prestasi pekerja. Fasa yang terakhir ialah pembuatan keputusan. Proses ini dipengaruhi oleh elemen penghakiman oleh penilai dan bergantung kepada sejauh mana proses pengintegrasian maklumat yang berlaku sebelumnya. Pada peringkat ini sejauh mana model pemprosesan maklumat kognitif yang dilalui dan diguna pakai oleh penilai akan menentukan sejauh mana keberkesanan pembuatan keputusan yang dibuat. Proses yang terlibat adalah secara berperingkat dan seperti mengikut satu urutan yang lurus. Sesungguhnya pada peringkat amalan sebenar, setiap fasa atau proses yang terlibat mempunyai kaitan yang sangat rapat dan sukar untuk dipisahkan (DeNisi \& rakan-rakan, 1984). Proses ini berlaku secara saling lengkap melengkapi dan apa yang berlalu pada mana-mana fasa adalah juga mempengaruhi proses berikutnya pada fasa yang lain.

\section{Konteks Penyelidikan}

Kajian ini dijalankan pada sistem penilaian prestasi sektor awam di Malaysia. Ini adalah selari dengan galakkan yang dibuat oleh sarjana 
dan penyelidik untuk melakukan kajian empirikal di sektor awam (Bissessar 2000; Jabroun \& Balakrishnan, 2000; O'Donnell \& O'Brien, 2000: Redman, Snape \& Thompson, 2000). Sektor awam memainkan peranan yang sangat penting di Malaysia. Bilangan pekerja yang teramai di Malaysia ialah pada sektor awam dan peruntukan yang terbesar dalam belanjawan tahunan adalah untuk sektor ini. Abdul Hamid (1996) dan Abdul Karim (1999) dalam konteks ini menegaskan bahawa aktiviti di sektor awam adalah merupakan nadi dan jantung kepada jentera pentadbiran kerajaan Malaysia. Secara spesifik, kajian ini dijalankan terhadap pegawai penilai prestasi yang bertugas di dalam klasifikasi perkhidmatan pendidikan di dalam perkhidmatan awam, Malaysia. Perkhidmatan pendidikan dipilih kerana sektor ini merupakan kumpulan terbesar penjawat sektor awam. Ini ditambah pula dengan kebenaran untuk menjalankan kajian yang diperoleh. Pengalaman penyelidik berkhidmat di sektor ini sebelumnya adalah sangat membantu dan memudahkan penyelidikan yang dijalankan. Ini memberi keyakinan dan kemudahan kepada penyelidik untuk memahami konteks kajian secara lebih komprehensif.

\section{Objektif Kajian}

Objektif kajian ini bertujuan untuk meneroka persepsi penilai (novis dan pakar) terhadap pelaksanaan model pemprosesan maklumat kognitif dalam sistem penilaian prestasi sektor awam di Malaysia. Objektif kajian lain adalah untuk mengenal pasti perbezaan persepsi antara penilai novis dan pakar dalam perkara yang berkenaan. Bagi tujuan itu, beberapa hipotesis kajian telah dikenal pasti untuk diuji iaitu;

H1. Terdapat perbezaan persepsi antara penilai novis dan pakar bagi fasa pemerhatian dalam pembuatan keputusan berkaitan prestasi.

H2. Terdapat perbezaan persepsi antara penilai novis dan pakar bagi fasa pengkategorian dalam pembuatan keputusan berkaitan prestasi.

H3. Terdapat perbezaan persepsi antara penilai novis dan pakar bagi fasa penyimpanan dalam pembuatan keputusan berkaitan prestasi.

H4. Terdapat perbezaan persepsi antara penilai novis dan pakar bagi fasa pengingatan kembali dalam pembuatan keputusan berkaitan prestasi. 
H5. Terdapat perbezaan persepsi antara penilai novis dan pakar bagi fasa pengintegrasian dalam pembuatan keputusan berkaitan prestasi.

H6. Terdapat perbezaan persepsi antara penilai novis dan pakar dalam pembuatan keputusan bagi tujuan penilaian prestasi.

\section{Reka Bentuk dan Metodologi Kajian}

Reka bentuk kajian ini adalah bukan eksprimen (non-experimental design). Metodologi kajian yang digunakan adalah bersifat kuantitatif. Penggunaan metodologi ini mempunyai kelebihan dari segi tingkat generalisasi yang dapat dibuat dan dari sudut memberi jawapan dan kesahan yang tinggi kepada permasalahan kajian (De Vaus, 1996; Easterby-Smith, Thorpe \& Lowe, 1991; Sekaran, 1992). Soal selidik telah digunakan sebagi teknik pungutan data. Soal selidik dipilih kerana teknik ini adalah sangat popular dan berkesan (dapat digunakan kepada jumlah responden yang besar, cepat dan menggunakan soalan yang standard). Dalam kajian ini soal selidik yang digunakan adalah dibentuk sendiri dan skala Likert 1 hingga 5 telah digunakan (1-Sangat Tidak Bersetuju, 2-Tidak Bersetuju, 3-Berkecuali, 4-Setuju, 5-Sangat Bersetuju). Aspek kesahan dan kebolehpercayaan item yang digunakan adalah seperti pada Jadual 1.

Jadual 1

Kesahan dan Kebolehpercayaan Item Kajian

\begin{tabular}{|c|c|c|c|c|c|c|}
\hline Variabel & $\begin{array}{l}\text { Jumlah } \\
\text { Item }\end{array}$ & $\mathrm{KMO}$ & $\begin{array}{c}\text { Ujian } \\
\text { Bartlett's }\end{array}$ & Eigenvalues & $\begin{array}{l}\text { ‘Variance } \\
\text { Explained' }\end{array}$ & $\begin{array}{c}\text { Cronbach } \\
\text { Alpha }\end{array}$ \\
\hline Pemerhatian 1 & 7 & 0.698 & 579.499 & 3.05 & 16.99 & 0.70 \\
\hline Pemerhatian 2 & 4 & 0.698 & 579.499 & 2.88 & 15.97 & 0.78 \\
\hline Pengkategorian & 7 & 0.682 & 1115.898 & 5.01 & 18.55 & 0.73 \\
\hline Penyimpanan & 8 & 0.730 & 417.420 & 3.50 & 26.89 & 0.76 \\
\hline $\begin{array}{l}\text { Pengingatan } \\
\text { kembali }\end{array}$ & 11 & 0.731 & 629.347 & 3.98 & 23.40 & 0.82 \\
\hline Pengintegrasian & 5 & 0.720 & 365.357 & 2.88 & 23.99 & 0.70 \\
\hline $\begin{array}{l}\text { Pembuatan } \\
\text { keputusan }\end{array}$ & 8 & 0.730 & 311.688 & 3.09 & 25.76 & 0.71 \\
\hline
\end{tabular}




\section{Statistik Deskriptif}

Populasi kajian terdiri daripada Pegawai Penilai Pertama (PPP) dan Pegawai Penilai Kedua (PPK) yang berjumlah seramai 330 dan dapat dikategorikan kepada dua kumpulan iaitu penilai novis dan penilai pakar. Kriteria penentuan kategori penilai adalah berdasarkan dua kriteria utama iaitu latihan sebagai penilai prestasi yang telah dihadiri dan tempoh masa menjadi pegawai penilai prestasi (sekurang-kurangnya 5 tahun). Sampel kajian terdiri dari 199 (58.9\%) pegawai penilai prestasi yang telah dikenal pasti melalui penggunaan teknik persampelan rawak mudah. Teknik ini dipilih kerana dapat memberi peluang yang sama kepada mereka yang terlibat untuk menjadi responden kajian dan tatacara pengurusannya adalah dapat dijalankan secara lebih sistematik. 155 soal selidik yang lengkap telah diterima dan mewakili $77.9 \%$ responden kajian. Dari segi jantina, $58.7 \%$ responden adalah lelaki, manakala $40.6 \%$ adalah wanita. Seorang responden tidak menjawab soalan. Dari segi etnik, $81.3 \%$ adalah daripada etnik Melayu, $7.4 \%$ adalah daripada etnik Cina, dan $0.7 \%$ adalah daripada etnik India. Dari segi umur, 3.3\% responden adalah dalam lingkungan umur $36-40$ tahun, $40.0 \%$ berumur antara 41-45. Majoriti responden (55.5\%) adalah dalam lingkungan umur 46-55 tahun. Dari segi pendidikan, 87.1\% memiliki ijazah pertama, manakala $12.3 \%$ mempunyai kelayakan peringkat sarjana. Seorang responden tidak menjawab soalan. Lebih daripada separuh (51.0\%), telah berkhidmat melebihi 20 tahun, manakala $47.8 \%$ berkhidmat selama 20 tahun, dan ke bawah. Dua responden tidak menjawab soalan. Dari segi kategori perkhidmatan, majoriti responden (51.5\%) adalah dalam kategori Pegawai Perkhidmatan Pendidikan siswazah, DG3. Dua responden tidak menjawab soalan.

\section{Dapatan Kajian}

Objektif kajian yang pertama ialah untuk mengetahui tentang persepsi kumpulan penilai prestasi terhadap pelaksanaan model pemprosesan maklumat dalam penilaian prestasi. Jawapan kepada soalan ini penting untuk memberi jawapan pada objektif kajian ini. Pemeriksaan terhadap purata skor bagi variabel model pemprosesan maklumat kognitif yang terlibat menunjukkan bahawa semua variabel terlibat mendapat purata skor yang melebihi 3.0 dan nilai ini menunjukkan kumpulan pegawai penilai prestasi melaksanakan fasa-fasa yang terlibat dalam model pemprosesan maklumat kognitif seperti yang ditunjukkan pada Rajah 2. Data ini mengambarkan 
bahawa semua pegawai penilai prestasi sedar dan mempunyai sikap yang positif terhadap model pemprosesan maklumat kognitif dalam pembuatan keputusan berkaitan prestasi pekerja. Untuk meyakinkan bahawa nilai purata adalah signifikan dari titik purata 3.0, ujian t bagi satu sampel telah dijalankan dan keputusannya adalah seperti pada Jadual 1.

Berdasarkan Jadual 1, keputusan ujian $t$ didapati sangat signifikan dari titik tengah $3.0(p<0.05)$. Ini mengesahkan lagi bahawa semua item yang terlibat berada pada tingkat yang positif. Keputusan di atas menunjukkan dengan jelas bahawa pegawai penilai prestasi mempunyai sikap yang positif terhadap model pemprosesan maklumat kognitif dalam pembuatan keputusan berkaitan dengan prestasi. Nilai min, dan ujian $\mathrm{t}$ membuktikan hakikat ini.

Objektif 2 kajian ini adalah untuk menentukan perbezaan sikap antara pegawai penilai prestasi novis dan pakar. Enam hipotesis telah dikenal pasti untuk diuji. Ujian telah digunakan dan beberapa andaian dipatuhi. Ini penting untuk memastikan ketepatan ujian ini adalah tinggi. Data yang digunakan dalam kajian ini menepati segala kriteria yang diperlukan dan dengan itu ujian $t$ bebas adalah sesuai untuk digunakan. Jadual 2 menunjukkan keputusan ujian $\mathrm{t}$ yang dijalankan. Dari jadual didapati nilai Ujian Levene melebihi 0.05, dan ini menunjukkan bahawa taburan varian bagi populasi adalah secara perbandingannya sama. Keadaan ini membolehkan nilai $t$, darjah kebebasan, dan nilai dua hujung signifikan untuk melihat jangkaan persamaan varian bagi menentukan sikap pegawai penilai prestasi terhadap model pemprosesan maklumat kognitif boleh digunakan.

Hipotesis H1-H6 bertujuan untuk memeriksa perbezaan dari segi sikap pegawai penilai prestasi novis dan pakar tentang perlaksanaan semua fasa yang terlibat dalam model pemprosesan maklumat kognitif pembuatan keputusan penilaian prestasi pekerja. Jadual 2 menunjukkan hasil ujian berkenaan. Daripada Jadual 2 didapati hanya hipotesis $\mathrm{H} 2$ sahaja yang signifikan dan disokong, iaitu bagi variabel 'Pemerhatian 2' dan mewakili isu atau aspek pemerhatian yang terhad. Nilai t bagi 'Pemerhatian 2' ialah 3.444, darjah kebebasan skor (df) ialah 153, dan nilai signifikan pada ujian 2 hujung ialah 0.001. Dengan itu, hipotesis kajian adalah diterima. Keputusan ini menunjukkan terdapat perbezaan yang signifikan antara pegawai penilai novis dan pakar dalam 'aspek pemerhatian yang terhad' dalam pembuatan keputusan penilaian prestasi pekerja.

212 IJMS 17 (2), 201-224 (2010) 


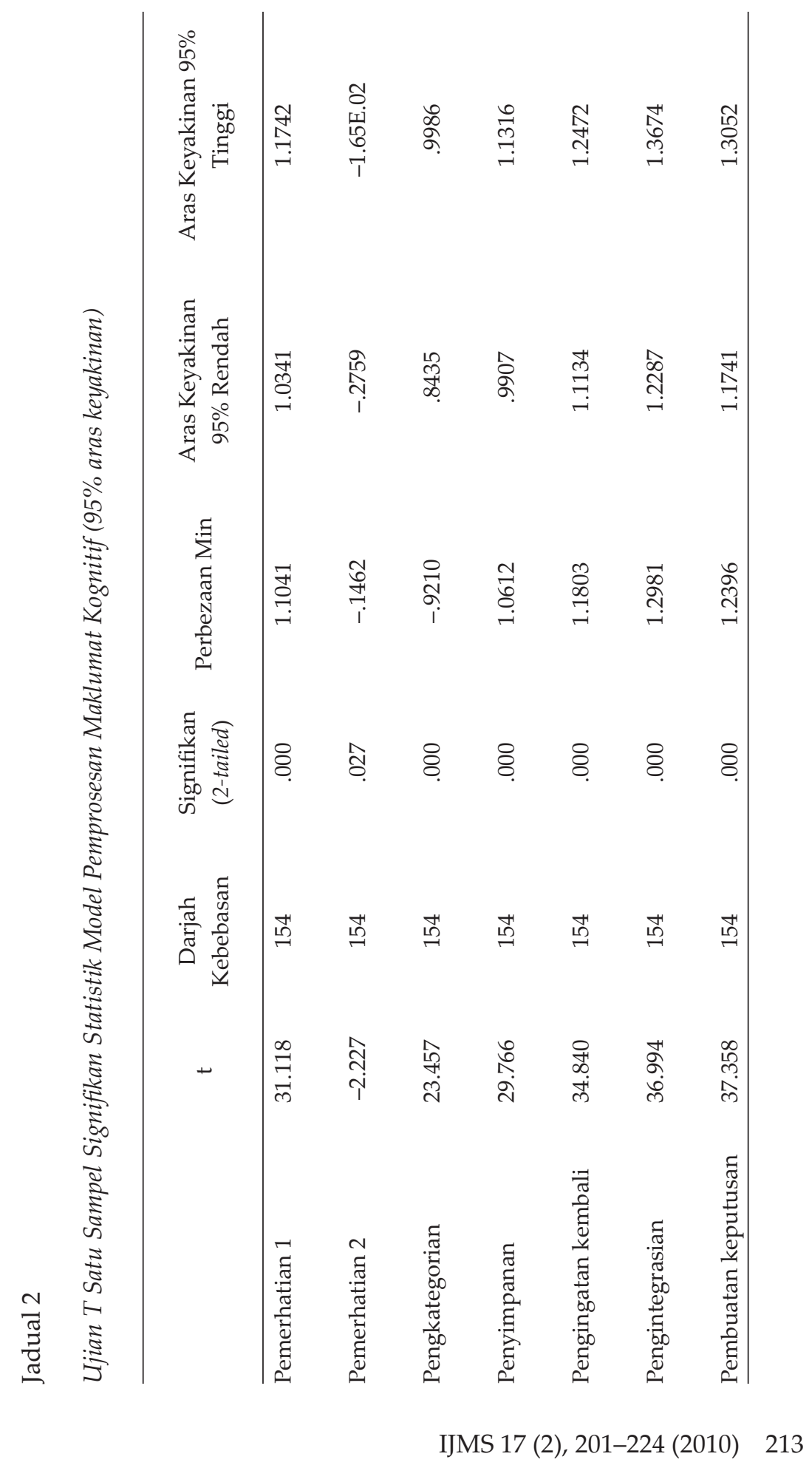




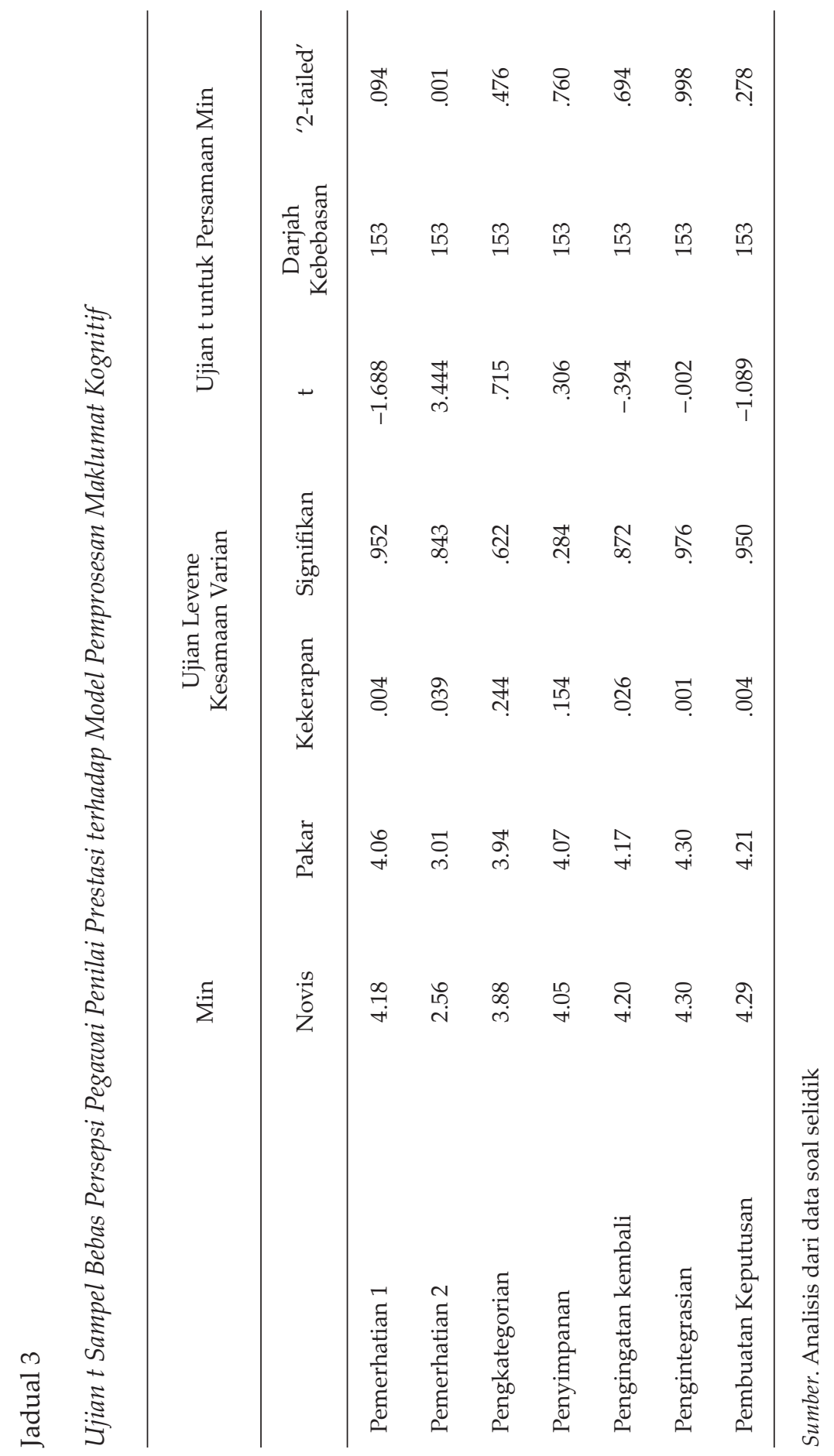

214 IJMS 17 (2), 201-224 (2010) 
Hipotesis H1, H3, H4, H5 dan H6 adalah tidak signifikan dan tidak disokong. Ini bermakna tidak ada perbezaan yang signifikan antara pegawai penilai novis dan pakar berkaitan dengan pelaksanaan model pemprosesan maklumat kognitif dalam pembuatan keputusan berkaitan dengan prestasi. Ujian signifikan dua hujung memperolehi nilai $\mathrm{p}>0.05$, dan membuktikan adalah tidak signifikan. Dengan itu, hipotesis nul diterima manakala hipotesis alternatif ditolak. Keputusan ini tidak menyokong semua hipotesis yang diuji kecuali H2 bagi aspek 'Pemerhatian 2'. Dari ujian yang dijalankan, didapati tidak ada perbezaan yang signifikan antara pegawai penilai novis dan pakar dalam pelaksanaan fasa Pemerhatian 1, pengkategorian, penyimpanan, pengingatan kembali, pengintegrasian dan pembuatan keputusan dalam model pemprosesan maklumat kognitif berkaitan dengan prestasi pekerja sektor awam di Malaysia.

\section{Perbincangan}

Objektif kajian adalah untuk meneroka persepsi pegawai penilai prestasi terhadap pelaksanaan sistem pemprosesan maklumat dalam pembuatan keputusan berkaitan dengan prestasi. Dapatan kajian dengan jelas menunjukkan pegawai penilai prestasi mempunyai persepsi yang positif terhadap perkara ini. Ini disokong oleh skor purata adalah melebihi 3.00 dan berdasarkan nilai ujian $t$ yang signifikan dari titik tengah. Ini menunjukkan kumpulan penilai prestasi memiliki persepsi yang positif terhadap model pemprosesan maklumat kognitif dan menyedari pentingnya fasa-fasa yang terlibat dalam proses berkenaan.

Pemeriksaan ke atas setiap fasa yang terlibat dalam model pemprosesan maklumat kognitif menunjukkan satu penemuan yang menarik. Pemerhatian adalah satu fasa yang sangat penting dalam model pemprosesan maklumat kognitif. Pegawai penilai prestasi menunjukkan bahawa mereka sedar tentang standard atau kriteria penting yang perlu dilakukan dalam membuat pemerhatian. Dapatan kajian mendapati mereka mempunyai objektif yang jelas. Objektif yang jelas sangat penting dan mempengaruhi bentuk pemerhatian yang dibuat. Ini selari dengan kajian Murphy, Philbin dan Adam (1989) yang menekankan pentingnya penilai mempunyai objektif pemerhatian yang jelas dan hal ini memberi kesan langsung kepada penilaian yang dijalankan. Penilai prestasi juga menunjukkan bahawa organisasi mempunyai model tingkah laku ideal yang menjadi asas kepada pemerhatian yang dijalankan. Mereka mengakui bahawa pemerhatian langsung terhadap prestasi individu pekerja adalah 
faktor yang terpenting dalam menentukan pengredan prestasi pekerja. Dalam kajian ini, pegawai penilai didapati telah memberi penekanan kepada perkara ini dan mereka telah menjalankan proses pemerhatian dengan serius.

Salah satu dapatan kajian yang penting ialah pegawai penilai prestasi didapati menunjukkan persepsi bahawa mereka berketrampilan dalam melakukan proses pemerhatian. Mereka memaklumkan kepada pekerja tentang pemerhatian yang dijalankan dari segi masa dan sebab dijalankan. Mereka juga didapati bersikap terbuka dan memberi ruang kepada pekerja untuk berbincang selepas pemerhatian dijalankan. Penilai prestasi juga didapati memberi penekanan kepada aspek positif prestasi pekerja jika dibandingkan aspek negatif. Sungguhpun begitu, mereka juga menyatakan bahawa aspek subjektif terhadap pekerja tidak dapat tidak, mempengaruhi proses pemerhatian yang dijalankan. Ini bermaksud faktor suka atau tidak pada seseorang individu mempengaruhi pemerhatian yang dibuat. Lanjutan itu penilai prestasi cuma memberi perhatian kepada beberapa aspek sahaja dari tingkah laku pekerja untuk diperhatikan. Dapatan kajian juga mendapati pemerhatian yang dijalankan hanya dibuat untuk tujuan menentukan ganjaran yang akan diberikan dan bukan bertujuan untuk pembangunan pekerja itu sendiri. Kepentingan pemerhatian dalam proses mendapatkan maklumat berkaitan prestasi pekerja yang didapati dalam kajian adalah selari dengan kajian yang dijalankan oleh penyelidik dan sarjana dalam bidang ini (Cardy \& Dobbins, 1994; DeNisi \& rakan-rakan, 1984; DeNisi, 1996; Feldman, 1981; Landy \& Farr, 1983; Murphy \& Cleveland, 1995; Wofford \& Goodwin, 1990, Rusli Ahmad, 2008).

Dapatan kajian juga mendapati penilai prestasi mempunyai persepsi yang positif terhadap fasa kedua iaitu pengkategorian maklumat. Maklum balas kajian menunjukkan responden memperolehi maklumat dari pelbagai sumber. Mereka menafikan bahawa maklumat hanya diperoleh daripada sumber yang sangat terhad sahaja. Mereka menambah bahawa pengetahuan dan interaksi mereka dengan seseorang pekerja adalah tidak memadai untuk mengkategori pekerja mengikut prestasi dengan sewajarnya. Penilai prestasi telah menyatakan beberapa cara telah diambil untuk membuat kategori bagi maklumat yang diperoleh. Salah satu sumber maklumat yang penting adalah daripada pekerja itu sendiri. Hal ini memerlukan pekerja berkenaan menyimpan rekod berkaitan dengan kerja dan digunakan untuk berbincang dengan penilai prestasi. Kajian juga mendapati penilai prestasi bersikap fleksibel dalam membuat klasifikasi terhadap prestasi pekerja. Penilai prestasi berkemampuan mengklasifikasikan prestasi pekerja berdasarkan pelbagai sumber. 
Ini menunjukkan bahawa penilai prestasi berkemampuan melaksanakan fasa ini dengan baik dan membuat pengkategorian maklumat yang tepat dalam perkara berkenaan. Pengkategorian juga dibuat dengan cara membandingkan prestasi individu dengan rakan sekerja mereka bagi tugas yang sama dilakukan. Salah satu sumber pengkategorian yang lain ialah berdasarkan model jangkaan yang ada dalam organisasi. Ideal model yang ada menyebabkan proses pengkategorian menjadi lebih mudah. Sungguhpun begitu, penilai prestasi juga mengakui bahawa proses meletakkan pekerja berdasarkan model jangkaan dan klasifikasi yang dibuat bukanlah satu proses yang rumit. Salah satu dapatan kajian yang menarik ialah penilai prestasi menunjukkan kebolehan dan keyakinan dalam membandingkan prestasi pekerja. Penilai didapati mempunyai ketrampilan yang tinggi dalam melaksanakan fasa pengkategorian maklumat. Penilai didapati tidak terpengaruh dengan faktor personaliti pekerja. Kajian mendapati pemerhatian adalah sumber yang paling dominan dalam pengkategorian maklumat prestasi pekerja. Kepentingan fasa ini dalam model pemprosesan maklumat kognitif telah diperakukan dan ditekankan oleh para pengkaji dan sarjana terdahulu (Feldman, 1981; DeNisi \& rakan-rakan, 1984; Wofford \& Goodwin 1990; Murphy \& Cleveland, 1995; DeNisi, 1996; Rusli Ahmad \& Nor Azman Ali, 2003).

Pemeriksaan pada fasa penyimpanan dalam model pemprosesan maklumat kognitif memperlihatkan beberapa dapatan kajian yang menarik. Penilai prestasi didapati mempunyai sistem tersendiri dalam menyimpan maklumat. Rekod disimpan menggunakan diari dan komputer. Ini penting kerana penilai prestasi sedar bahawa mereka tidak mampu menyimpan dan mengingati segala maklumat. Dapatan ini selari dengan kajian yang dijalankan oleh Maurer, Palmer dan Ashe (1993) yang menyatakan bahawa penggunaaan diari dalam menyimpan maklumat dapat memberikan maklumat yang lebih tepat, dipercayai dan berkesan. Proses mengingati semula maklumat berkaitan akan menjadi lebih mudah apabila diperlukan dalam pembuatan keputusan. Murphy dan rakan-rakan, (1989) dalam hubungan ini menegaskan bahawa faktor ingatan penilai adalah sangat penting dalam menentukan ketepatan keputusan yang dibuat. Dalam kajian ini penilai prestasi didapati menyedari pentingnya penyimpanan maklumat dibuat dengan memuaskan. Ini penting untuk memastikan maklumat penting adalah tidak hilang dan mudah untuk digunakan pada masa yang diperlukan (Tulving, 1974).

Penilai prestasi juga didapati mempunyai persepsi yang positif terhadap aplikasi fasa pengingatan semula (min, 4.18). Didapati 
penilai prestasi menggunakan pelbagai sumber untuk tujuan pengingatan semula. Pendapat daripada pihak lain juga mereka gunakan. Mereka mendapatkan maklumat daripada beberapa sumber utama. Mereka memeriksa ketepatan sumber yang diperoleh daripada pihak lain. Dalam proses ini penilai prestasi mementingkan integrasi maklumat daripada pelbagai sumber yang boleh dipercayai. Mereka sedar bahawa mereka tidak boleh hanya bergantung kepada daya ingatan masing-masing sahaja. Dalam proses ingatan semula ini juga didapati penilai prestasi memberi perhatian yang lebih untuk mendapatkan maklumat yang berkaitan dengan prestasi untuk tugas utama (core business) pekerja berdasarkan analisis tugas yang telah dikenal pasti. Adalah didapati tingkah laku di luar masa pekerjaan tidak menjadi unsur utama dalam menentukan prestasi pekerja. Kualiti kerja menjadi keutamaan berbanding dengan kuantiti kerja yang dilakukan. Penilai prestasi juga didapati memberi penekanan kepada prestasi aktiviti kerja yang berbentuk kumpulan.

Integrasi adalah fasa yang penting dalam model pemprosesan maklumat kognitif. Nilai min yang diperolehi adalah 4.30. Keputusan ini menunjukkan bahawa penilai prestasi memiliki persepsi yang positif terhadap perkara di atas. Implikasi dapatan ini ialah penilai prestasi mengambil kira maklumat dari semua pihak dan menggunakan pendekatan menyeluruh dalam memproses maklumat yang diperoleh. Penilai prestasi didapati tidak membuat keputusan hanya berdasarkan satu aspek utama sahaja. Beberapa aspek utama pekerjaan telah diambil kira seperti kebolehan, kemahiran, dedikasi, kreativiti, inovasi serta faktor personaliti pekerja. Bagaimanapun, untuk aspek personaliti, impaknya adalah kecil ( $\min -2.85)$. Maklumat berkaitan tugas utama (core business) menjadi perhatian utama. Didapati kelayakan akademik tertinggi yang diperoleh pekerja bukanlan faktor yang signifikan dalam menentukan keputusan berkaitan prestasi kerja. Mereka juga menyatakan bahawa peristiwa atau perkara lepas yang berkaitan prestasi pekerjaan yang baru berlaku besar nisbahnya dalam mempengaruhi penilaian prestasi jika dibandingkan dengan peristiwa atau perkara yang telah lama berlaku.

Bagi fasa terakhir, iaitu pembuatan keputusan, terdapat beberapa perkara menarik untuk diperhatikan. Kumpulan penilai prestasi jelas menekankan bahawa pembuatan keputusan hendaklah dijalankan secara sistematik dan dengan seadil mungkin. Deskripsi tugas pekerja menjadi rujukan utama dan panduan dalam melaksanakan proses ini. Dalam hubungan ini penilai prestasi menyatakan dengan jelas bahawa sasaran kerja tahunan menjadi panduan utama mereka. 
Selain daripada itu pertimbangan juga diberi kepada informasi dan perbincangan yang dibuat dengan pihak lain (second opinion). Kumpulan penilai prestasi juga menyatakan bahawa mereka mengadakan perbincangan dengan pekerja sebelum keputusan dibuat. Penyelidik dan sarjana yang melakukan kajian tentang perkara ini juga menyuarakan bahawa fasa ini amat penting dalam menentukan kesahihan dan ketepatan keputusan yang diambil (Landy \& Farr, 1980, 1983; DeNisi \& rakan-rakan, 1984; Wofford \& Goodwin, 1990; Corner, Kinicki \& Keat, 1994; Murphy \& Clevelan, 1995; DeNisi, 1996).

Objektif kedua kajian ini ialah untuk menentukan perbezaan persepsi antara dua kumpulan penilai (novis dan pakar) berkaitan dengan aplikasi model pemprosesan maklumat kognitif. Dapatan kajian mendapati tidak terdapat perbezaan yang signifikan antara novis dan pakar tentang perkara berkaitan di atas kecuali untuk 'Pemerhatian 2'. Implikasi dapatan ini melibatkan dua perkara. Pertama, latihan didapati tidak memberi kesan kepada aplikasi model pemprosesan maklumat kognitif. Dapatan kajian bercanggah dengan dapatan kajian yang dijalankan oleh Ghullam (1993). Beliau mendapati latihan yang dijalankan telah menambahbaikkan ketepatan proses pembuatan keputusan. Adnan (1999) dalam kajiannya juga mendapati bahawa latihan adalah penting kepada organisasi dengan cara dapat mengurangkan masalah yang timbul, peningkatan komitmen dan memenuhi keperluan dan tuntutan pekerjaan. Perkara ini tidak mengejutkan kerana mereka (novis) memperoleh kemahiran dan keyakinan untuk melakukan tugas itu berdasarkan penglibatan langsung mereka dengan tugas yang diberikan itu. Mungkin latihan sambil kerja yang dijalankan berserta sistem pemantauan berkesan memudahkan mereka melaksanakan tugas mereka dengan jayanya.

Salah satu implikasi penting kajian ini ialah lama masa berkhidmat (melebihi 5 tahun) didapati tidak mempunyai kaitan yang signifikan dengan aplikasi fasa-fasa terlibat dalam model pemprosesan maklumat kognitif. Keputusan kajian menunjukkan bahawa penilai prestasi novis mempunyai persepsi yang positif dalam menjalankan tugas mereka dan mempraktiskan fasa yang terlibat dalam model pemprosesan maklumat kognitif. Adalah didapati bentuk dan jenis tugas yang mereka jalankan dan tanggungjwab yang dipikul menyebabkan mereka mampu menjalankan tugas dengan baik dan berkesan. Dapatan ini selari dengan apa yang ditegaskan oleh Herzberg (1966) dalam Teori Dua Faktor. Penilai prestasi mungkin menggunakan jawatan yang mereka pegang dan tugas yang perlu diselesai dan mengaitkannya dengan objektif yang telah 
ditentukan. Dalam hubungan ini objektif dan matlamat tugas yang jelas mempunyai peranan yang besar dalam membantu pelaksaan tugas ini. Ini kerana matlamat yang jelas terhadap pekerjaan mereka mungkin membantu mereka dapat menjalankan tugas dengan baik.

\section{Kesimpulan}

Makalah penyelidikan ini memberi perhatian kepada soal selidik yang dijalankan bagi meneroka dan menentukan persepsi pegawai penilai prestasi sektor awam di Malaysia berkaitan dengan model pemprosesan maklumat kognitif dalam pembuatan keputusan. Perbincangan bermula dengan penghuraian deskriptif penilaian prestasi pekerja, teori pemprosesan maklumat dan model pemprosesan maklumat kognitif. Matlamat dan tujuan kajian juga telah dihuraikan. Berdasarkan data dari kajian yang dijalankan adalah jelas bahawa pegawai penilai prestasi sama ada novis atau pakar, kedua-duanya mempunyai sikap yang positif terhadap pelaksanaan model pemprosesan maklumat kognitif dalam pembuatan keputusan prestasi pekerja. Dapatan kajian menunjukkan tidak terdapat perbezaan yang signifikan antara dua kumpulan penilai prestasi (novis dan pakar) dalam pembuatan keputusan dari sudut model pemprosesan maklumat kognitif.

\section{Nota Akhir}

Kertas kerja ini telah dimuatkan di dalam prosiding Persidangan Kebangsaan Pengurusan Sumber Manusia Ke-2, anjuran Faculty of Human and Social Development, Universiti Utara Malaysia, 2004.

\section{Rujukan}

Abdul Hamid, A. S. (1996). World class public service. Kuala Lumpur: Pelanduk Publications.

Abdul Karim, M. R. (1999). The challenging of Malaysia public service. Kuala Lumpur: Pelanduk Publications.

Adnan, A. S. A-A. (1999). Human resource development training and development practices and related organisational factors in Kuwaiti organisations: An investigation of the policies and practices of Kuwaiti government and privateljoint venture organisations towards training and development and organisational related factors (Unpublished doctoral dissertation). University of Bradford Management Centre, United Kingdom. 
Ahmad, R., \& Spicer, D. P. (2000). Practice of performance appraisal in the Malaysian public service: Proposal for research exploring the cognitive processing model. First Symposium on Graduate Management Research, Universiti Utara Malaysia (1516 November).

Argyris, C. (1994). Good communication that block learning. Harvard Business Review, July-August, 77-85.

Armstrong, M. (1998). Managing people: A practical guide for line managers. London: Kogan Page.

Armstrong, M. (1999a). How to be an even better manager (15th ed.). London: Kogan Page.

Armstrong, M. (1999b). Employee reward (2nd ed.). Exeter: Sheorgmun Press.

Bartol, K., \& Locke, E. (2000). Incentives and motivational. In Rynes, S., \& Gerhart, B. (Eds), Organisation compensation. San Francisco: Jossey-Bass.

Beck De, A., O'Sullivan, P. S., \& Boh Le. (1995). Increasing the accuracy of observer ratings by enhancing cognitive processing skills. American Journal of Pharmaceutical Education, 59 (3), 228-235.

Bissessar, A. M. (2000). The introduction of new appraisals systems in the public services of the Commonwealth Caribbean. Public Personnel Management, 29(2), 277-292.

Bratton, J., \& Gold, J. (1999). Human resource management: Theory dan practice. London: Macmillan Business.

Brown, A. D. (1999). The six dimensions of leadership. London: Random House Business Book.

Cardy, R. L., \& Dobbins, G. H. (1994). Performance appraisal: Alternative perspective. Cincinnati, $\mathrm{OH}$ : Southwestern Publishing.

Cooper, W. (1981b). Ubiquitous halo. Psychological Bulletin, 90, 218244.

Corner, P. D., Kinicki, A. J., \& Keats, B. W. (1994). Integrating organisational and individual information processing perspectives on choice. Organisation Science, 5(3), 145-155.

Danerson, D. B. (1994). Performance appraisal: A different approach. FBI-Law Enforcement Bulletin, April, 18-22.

De Vaus, D. A. (1996). Survey in social research. London: George Allen and Unwin.

DeNisi, A. S. (1996). A cognitive approach to performance appraisal: A program of research. London: Routledge.

DeNisi, A. S., Cafferty T. P., \& Meglino, B. M. (1984). A cognitive view of performance appraisal process: A model and research propositions. Organizational Behaviour dan Human Decision Processes, 33, 360-396. 
Easterby-Smith, M., Thorpe, R., \& Lowe, A. (1991). Management research. London: Sage Publication.

Feldman, J. M. (1981). Beyond attribution theory: Cognitive processes in performance appraisal. Journal of Applied Psychology, 66, 127-148.

Furnham, R. (1994). Does money motivate? The Sunday Times, 9 October. In Billsberry, J. The effective manager: Perspective and illustrations. London: Sage Publication.

Ghulam, S. A. G. G. (1993). Distributive justice vs procedural justice. Perceptions of fairness of Saudi Arabian civil service employees in their performance appraisal system (Unpublished doctoral dissertation). The University of Arizona.

Hamilton, V., \& Warburton, D. M. (1979). Human stress and cognition: An information processing approach. Chichester: John Wiley \& Son.

Herzberg, F. (1966). Work and the nature of man. Cleveland: World Publishing.

Ilgen, D. R., \& Feldman, J. M. (1983). Performance appraisal: A process focus. Organisational Behaviour, 5, 141-197.

Jabroan, N., \& Balakrishnan, V. (2000). Participation and job performance in the Malaysian public service department. International Journal of Commerce and Management, 10 (3/4), 5666.

Kessler, I. (2000). Performance appraisal. In S. Banch, \& K. Sisson (Eds.), Personnel management: A comprehensive guide to theory and practice (3rd ed.). London: Blackwell Press.

Landy, F. J., \& Farr, J. L. (1983). The measurement of work performance: Methods, theory and applications. New York: Academic Press.

Landy, F. J., \& Farr, J. L. (1980). Performance rating. Psychological Bulletin, 87, 72-107.

Lawler, E. E. (1990). Strategic pay: Aligning organisational strategies and pay systems. San Francisco: Jossey Bass.

Malaysian Public Service, (1991). Improvement and development in the public service. Kuala Lumpur: Jabatan Percetakan Negara.

Maurer, T. J., Palmer, J. K., \& Ashe, D. K. (1993). Diaries, checklists, evaluations dan contrast effect in measurement of behavior. Journal of Applied Psychology, 78(2), 226-231.

Millward, N., Bryson, A., \& Forth, J. (2000). All change at work? London: Routledge.

Murphy, K. R., \& Cleveland, J. N. (1995). Understanding performance appraisal: Social, organizational and goal-based perspective. California: Sage Publication. 
Murphy, K. R., \& Cleveland, J. N. (1991). Performance appraisal: An organisational perspective. Needham Heights, MA: Allyn and Bacon.

Murphy, K. R., Philbin,T. A., \& Adams, S. R. (1989). Effect of purpose of observation on accuracy of immediate and delayed performance ratings. Organisational Behaviour dan Human Decision Processes, 43, 336-346.

Neiser, U. (1967). Cognitive psychology. New York: Appleton-CenturyCrofts.

Neisser, V. (1976). Cognitions and reality: Principles and implications of cognitive psychology. San Francisco: Freeman.

O'Donnell, M., \& O'Brien J. (2000). Performance-based pay in the Australian public service. Employee perspectives. Review of Public Personnel Administration, Spring 2000, 20-34.

Perry, J. (1995). Compensation, merit pay and motivation. In S.W. Hays, \& R.C. (Eds.), Kearney, Public personnel administration: Problems and prospects. New Jersey: Prentice Hall.

Public Service Department. (1992). New performance appraisal system in the Malaysian public service. Service Circular Number 4, Kuala Lumpur: National Printing Department.

Redman, T., Snape, E., Thompson, D., \& Yan, F. K-C. (2000). Performance appraisal in A NHS Hospital. Human Resource Management Journal, 10(1), 48-62.

Rusli Ahmad, \& Noor Azman Ali, (2003). The use of cognitive mapping technique in management research: Theory and practice. Management Research News, 26(7), 1-15.

Rusli Ahmad, \& Nor Azman Ali, (2004). Performance appraisal decision in the Malaysian Public Service, International Journal of Public Sector Management, 17(1) 48-64.

Rusli Ahmad, \& Spicer, D. P. (2002). A study of cognitive processing models used in the appraisal system: The Malaysian public service. Asian Academy of Management Journal, 7(2), 1-16.

Rusli Ahmad, \& Spicer, D. P. (2006). Cognitive processing models in performance appraisal: Evidence from the Malaysian education system. Human Resource Management Journal, 16 (2), 214-230.

Rusli Ahmad. (2007). Employees appraisal: Everything you have always wanted to know, Kuching: RS Group.

Rusli Ahmad. (2008). Employee appraisal and cognitive information processing system. Kota Samarahan: UNIMAS Publication.

Sekaran, U. (1992). Research methods for managers: A skill-building approach (2nd ed.). New York: John Wiley \& Son.

Thornton, G. C., \& Zorich, S. (1980). Training to improve observer accuracy. Journal of Applied Psychology, 65, 351-354. 
Tulving, E. (1974). Recall and recognition of semantically encoded words. Journal of Experimental Psychology, 5, 207-232.

Wofford, J.C., \& Goodwin, V.L. (1990). Effects of feedback on cognitive processing and choice of decision style. Journal of Applied Psychology, 75, 603-612.

Wyer, R. S., Scrull, T. K., Gordon, S. E., \& Hartwick , J. (1982). Effect of processing objectives on recall of prose material. Journal of Personality and Social Psychology, 43, 674-688. 